\title{
INFLUENTIAL FACTORS IN CHOOSING HIGHER EDUCATION INSTITUTION: A CASE STUDY OF A PRIVATE UNIVERSITY IN SURABAYA
}

\author{
Adelina Proboyo ${ }^{1^{*}}$; Ricky Soedarsono ${ }^{1}$ \\ ${ }^{1}$ International Business Management Program \\ Faculty of Economics, Petra Christian University \\ Jl. Siwalankerto 121-131, Surabaya 60236 \\ E-mail: adelina@petra.ac.id; ricky@petra.ac.id \\ *Korespondensi penulis
}

\begin{abstract}
Nowadays, tertiary education has taken more important role for Indonesian people. The growing number of tertiary education enrollment rate accompanied by the increasing number of higher education insitutions in Indonesia show that there is opportunity as well as threat for higher education insitutions in Indonesia. The purpose of this research is to know what factors influence the high school students in choosing their higher education institution. Specifically, this research wants to help one of the best private universities in Surabaya to improve its competitiveness compared to other higher education institutions. The respondents of the research are 426 students from several high schools in Surabaya. The analysis is done using descriptive statistics to find out which factors are the most significant ones. From the research, it is found out that the students' interest, the ability to follow the courses, and the parents' advice are the top three significant factors that influence the high school students in choosing their higher education institution. For the attributes of the institution, the reputation and the values of the institution as well as the success of its alumni are the top three factors that influence the decision in choosing the higher education institution.
\end{abstract}

Keywords: higher education, personal interest, external influences, attributes of higher education insitution

\begin{abstract}
Abstrak: Peran Pendidikan Tinggi menjadi semakin penting bagi penduduk Indonesia saat ini. Semakin tingginya jumlah pendaftar untuk Pendidikan Tinggi seiring dengan semakin banyaknya jumlah Perguruan Tinggi di Indonesia memberikan peluang sekaligus ancaman untuk Perguruan Tinggi di Indonesia. Tujuan umum dari penelitian ini adalah untuk mengetahui faktor-faktor apa saja yang mempengaruhi siswa-siswi SMA dalam memilih Perguruan Tinggi. Tujuan khusus penelitian ini adalah untuk membantu salah satu universitas swasta terbaik di Surabaya untuk meningkatkan daya saingnya dibandingkan dengan Perguruan Tinggi lainnya. Responden dari penelitian ini adalah 426 siswa-siswi dari beberapa SMA di Surabaya. Analisa deskriptif dilakukan untuk mengetahui faktor-faktor apa saja yang paling mempengaruhi pilihan Perguruan Tinggi. Hasil penelitian menunjukkan kalau minat siswa-siswi, kemampuan untuk mengikuti mata kuliah, dan saran dari orangtua merupakan tiga faktor paling penting yang mempengaruhi siswa-siswi SMA dalam memilih Perguruan Tinggi. Untuk atribut Perguruan Tinggi, reputasi dan nilai yang dianut Perguruan Tinggi serta kesuksesan alumni dari Perguruan Tinggi tersebut menjadi tiga faktor utama yang mempengaruhi keputusan pemilihan Perguruan Tinggi.
\end{abstract}

Kata kunci: Perguruan Tinggi, minat pribadi, pengaruh luar, atribut Perguruan Tinggi.

\section{INTRODUCTION}

Education is very important foundation to develop a country. The previous Indonesian President, Susilo Bambang Yudhoyono said that the absolute requirement for a country's advancement is on its education and health sector (Kompasiana, 2014). The same thing was also mentioned by the current president, Joko Widodo. He said that the improvement of a country's competitiveness starts from the education of its citizens (Munir, 2014). That is why, the government makes education as a priority in its policy and program.

With the fast development of science and technology in this globalization era, the role of higher education is getting more and more important. The development of education in Indonesia is very fast, including the higher education. As you can see from
Figure 1, the gross enrollment rate for tertiary education in Indonesia is getting higher and higher from year to year.

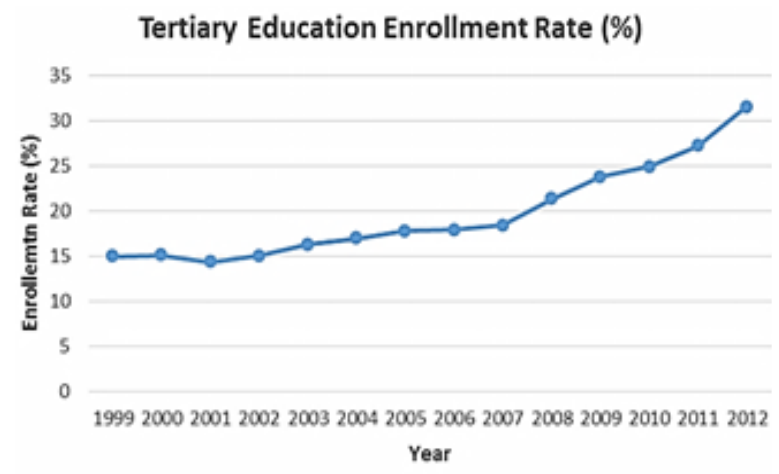

Source: UNESCO Institute of Statistics (n.d.)

Figure 1. Gross Enrollment Rate of Tertiary Education in Indonesia 
In addition, more and more higher education institutions, such as academies, polytechnic, universities, institutes, and vocational school are opened in Indonesia, as you can see in Table 1 .

Table 1. The Development of Higher Education Institutions

\begin{tabular}{cc}
\hline Year & Number of Higher Education Institutions \\
\hline 2005 & 2,428 \\
2006 & 2,581 \\
2007 & 2,730 \\
2008 & 2,929 \\
2009 & 3,081 \\
2010 & 3,098 \\
2014 & 4,329 \\
\hline
\end{tabular}

Source: Islam University of Indragiri (n.d.), Dikti (n.d.)

East Java, one of the growing provinces in Indonesia, has the second highest number of higher education institutions compared to other provinces in Indonesia. For academic year 2011/2012, the number of higher education institutions in East Java are 341, after West Java with its 398 institutions (Ministry of Education and Culture, 2012). As of now, the number of higher education institutions in East Java increases to 483 institutions, with 438 are private institutions.

With this increasing enrollment rate as well as the growing number of higher education institutions, the tight competition among higher education institutions cannot be avoided. With various facilities and programs offered by each higher education institution, people become more selective in choosing their place for education.

This tight competition also influences one of the best private universities located in Surabaya, East Java. Among 164 higher education institutions that have been accredited and among 21 higher education institutions that are accredited $\mathrm{A}$, this private university is the only private universities in Surabaya that gets A accreditation (Badan Akreditasi Nasional Perguruan Tinggi, n.d.).

Despite this great achievement, the ranking of this private university based on Webometrics decreeses from time to time.

From $8^{\text {th }}$ rank in July 2013 , it decreases to $12^{\text {th }}$ rank in January 2014. Then, it decreases again to $16^{\text {th }}$ rank in July 2014. This fact is even surprising, knowing that the number of Indonesian higher education institutions that are evaluated decreases from 410 institutions in January 2014 to 401 institutions in July 2014 (Kopertis Wilayah XII Maluku and North Maluku).

This decreasing rank shows that this university has lost some of its competitiveness compared to other higher education institutions. With decreasing number of higher education institutions that are evaluated, the ranking of the university decreases instead of increases. This means that other higher education institutions in Indonesia have outperformed this private university.

There are many researches that try to analyze what factors influences the students in choosing the higher education institutions. However, as far as the researcher's knowledge, there has been few researches which focus on private university. Not only that, there has not been any research focuses on private universities in Surabaya, although Surabaya is actually considered as one of the cities that are mostly chosen by the students, especially for tertiary education (Surabaya.go.id, n.d.).

This research will focus on knowing the factors that influence the potential students in choosing higher education institutions in Surabaya. By knowing all those factors, it is expected that this private university will be able to increase its competitiveness in the future.

\section{LITERATURE REVIEW}

Ming (2010) has developed a general conceptual model of student college choice that is adapted from Champ (1981) and Ismail et al. (2009). This conceptual model will be used as the basis for this research. The model suggests that the students' decision for higher education institution is influenced by three factors. The first factor is student characteristics. According to Washburn (2002), student characteristics in the college choice involves "breadth and variety of characteristics that impact students' college choice" (as cited in Burns, 2006). These characteristics include interest of the students as well as student's aptitude/ability (Burns, 2006). Past researches show that personal interest is the strongest factor that will influence the students in choosing their higher education institutions (Seymour \& Hewitt, 1997; McInnis, James \& Hartley, 2000; Mahani \& Molki, 2011, Misran et al., 2012). When students are interested in particular subject, they tend to take serious effort and commit fully on learning that particular subject (Yiv \& Secombe, 1999; Mustapha \& Long, 2010; Christie, Munro \& Fisher, 2004). In addition, Manski \& Wise (1983) proves that student's ability is the best predictor for college application (as cited in Irwin, 2008). Higher education institutions often publish the test scores and class rank of its entering classes and thus, directly discourage applications from students with low test scores or with poor high school records. As a result, when the high school students want to choose their higher education 
institutions, they often self-select the institutions and apply only to institutions that are matched with their academic ability (Champ, 1981).

The second factor is external influences. According to Ming (2010), external influences come from parents, friends, and other individuals. Parents and friends have been proven to have significant influence in the students' decision in choosing higher education institutions (Ming, 2010; Misran et al., 2012). Furthermore, Kohn, Manski, and Mundel (1976) and Manski and Wise (1983) have proven that friends attending the college is one of the significant factors that will influence the choice of higher education institutions (as cited in Ming, 2010). Last but not least, Ming (2010) also mentions that family members, teachers, guidance counselors, and admission counselors can also influence the student's choice for higher education institution.

Thirdly, attributes of higher education insitutions will also influence the students' choice for higher education institution. These attributes can be divided into two: (1) Higher education attributes and (2) The marketing effort made by higher education institutions. Attributes of higher education can include location of the institutions, the programs offered, the reputation of the institutions, the facilities given by the institutions, the cost of education, the job opportunities, etc. Baharun (2002) finds that the students' choice for higher education institutions is also determined by types of academic programs available, quality of education, faculty qualification as well as accessible and convenient location of the institutions. Not only that, based on Sevier (1997), the students' choice is also influenced by what the graduates do as well as the contributions that the graduates do for the society.

The marketing effort made by higher education institutions to communicate with the students involves the advertising made by the institutions, the campus visit, the representatives of higher education insitutions during campus visit, etc.

\section{RESEARCH METHOD}

This research is a quantitative research in which questionnaires are used as the main instrument to collect data. The sampling method is simple random sampling with the respondents are high schoolers from several schools in Surabaya. For this research, the students will be asked a list of questions related to the factors that will influence them in choosing higher education institution. The questionnaire will be divided into three main parts. The first part will be demographic of the respondents, such as gender, city, major, and choice of university. The second part will discuss about the influential factors in relation to the student characteristics as well as the marketing effort made by higher education institutions. The third part will be about the influential factors related to the attributes of higher education institutions. Among many questionnaires distributed, only 426 valid questionnaires will be used for further analysis.

The main analysis will be descriptive statistics. The analysis will cover the profile of the respondents and students' influential factors related to their choice for higher education institution. The factor that is chosen mostly by the respondents becomes the most influential factor for the institution choice.

The analysis for the influential factors will be separated into two main parts. The first part will discuss about the influential factors in relation to the student characteristics and the external influences. The second part will discuss about the attributes of higher education institutions.

\section{RESULTS AND DISCUSSION}

\section{Profile of the Respondents}

About $62.4 \%$ of the respondents are female, while the rest are male students. In addition, $82.4 \%$ of the respondents come from Surabaya, $8 \%$ is from Sidoarjo, while the others come from various cities in Indonesia. Furthermore, $62.4 \%$ are from science major while $37.6 \%$ is from social major.

Related to the choice of university, $81.5 \%$ agree that they will choose the program first and then university. On the other hand, $18.5 \%$ prioritize on choosing the university first before choosing the program.

\section{Influential Factors}

As being mentioned earlier, there are three main factors that will influence the potential students in choosing higher education institutions, including university. In this case, the respondents are asked to choose and rank five factors that will mostly influence them in choosing a higher education institution. The factors will be divided into two parts: (1) Influential factors related to student characteristics as well as external influences, and (2) Influential factors related to the attributes of the institutions.

For the student characteristics and external influences, the personal interest has become the most significant factors that influence the high school students in choosing a higher education institution. About 325 students (76.29\%) choose personal interest 
as their most important factors (rank \#1) and a total of 419 respondents choose personal interest as the factor that will influence their decision in choosing higher education institution. This is in line with the previous researches by Seymour \& Hewitt, 1997; McInnis, James \& Hartley, 2000; Mahani \& Molki, 2011 (as cited in Misran et al., 2012). When a student finds a program that suits his/her interest, he/she will find and apply to the best institution that is well known for that particular program (Fizer, 2013).

The second most significant factor is the advice from the parents. 388 respondents consider the parents' advice in choosing a higher education institution. This is consistent with previous researches made by Hossler, Schmidt, \& Vesper (1999), Cabrera and La Nasa (2000), Ceja (2001, 2006), Kim \& Schneider (2005), Kusumawati et al. (2010) in which the influence from parents is found to be an important factor for undergraduate students in deciding a university. Parents are the key factor in relation to the students' decision to pursue higher education (Ceja, 2001, 2006). According to Kusumawati et al. (2010), the suggestion from parents is related to funding support. Financial support which is often related to parental influence is directly related to the choice of higher education institution. Previous data shows that the influence from parents has a stronger impact on the choice of university when the students are financially dependent on their parents (Kusumawati et al., 2010). Since all respondents for this research are still in high school and they are financially dependent on their parents, it makes sense that the parents' advice is one of the significant factors that influence the high schoolers to enter particular institution and program.

Last but not least, the third significant factor is the students' expectation about their ability in following the courses if they decide to join the program. Around 378 respondents agree that their ability to join the courses in the program will determine their choice for the program. Based on Hossler (1984), when the students are aware that they will be able to achieve academic success in college, they will try to take post secondary education (as cited in Ming, 2010). Same thing applies for the program. If the students believe that they have the ability the follow the courses in a particular program, they will decide to enter that particular program in an institution.

For the attributes of the institutions, more than half of the total respondents (216 respondents) consider reputation of the institution as the most significant factor in influencing their choice for a higher education institution. In total, 342 respondents (80.28\%) agree that reputation of the institution is an important factor to be considered in choosing higher education institution. This is inline with previous researches which also find out that reputation of the insitutions is the most important factor in student's decision to choose higher education institutions (Manski \& Wise, 1983; Chapman \& Jackson, 1987; Moogan and Baron, 2003; Goenner \& Snaith, 2004; Briggs, 2006; Ancheh, Krishnan and Nurtjahja, 2007; Wiese, van Heerden, Jordaan et al., 2009; Schoenherr, 2009; Afful-Broni \& Noi-Okwei, 2010, Kusumawati et al., 2010). It is believed that the more reputable the university, the higher the opportunity to find a job easily after graduation or the higher the guarantee for the students to obtain a well-paid job after graduation (Kusumawati et al., 2010).

The second influential factor from the attributes that is considered important is the success of the alumni. This shows the same result as Sevier (1997) in Ming (2010). Previous researches show that the availability of good job prospect after graduation is considered as an important factor in choosing higher education institutions (Ancheh et al., 2007; Kusumawati et al., 2010). In line with those researches, this research shows that the success of alumni of the institution, which is closely related to the job prospect in the future, is indeed an important factor that will influence the high school students in choosing their higher education institution. If most of the alumni of the institution have successful career, it shows that entering that particular institution will give the students a higher chance to secure a better-paid job.

Last but not least, the values hold by the institution will also influence the high school students in choosing a higher education institution. Values are proven to have significance influence on the consumer behavior and thus, acts as determinant in his/her purchase decision (Kaze, 2010). The congruence between the values offered by a brand and those hold by the consumers is very important in influencing their purchase decision. "At the moment of truth, when a consumer turns thought into action and actually buys a product or service, it is the fit between a consumer's values and the values they perceive in a brand that matter" (Bloching \& Posdorf, 2013). Same thing applies for the choice of higher education instution. When the values hold by a particular higher education institution match with the student's values, the probability for the students to choose that institution as a place to study will be higher. 
Table 2. Influential Factors Related to Student Characteristics and External Influences

\begin{tabular}{|c|c|c|c|c|c|c|}
\hline Factors & Rank \#1 & Rank\#2 & Rank\#3 & Rank\#4 & Rank \#5 & Total \\
\hline My interest & 325 & 66 & 14 & 8 & 6 & 419 \\
\hline $\begin{array}{l}\text { My ability to follow the courses in the } \\
\text { program }\end{array}$ & 53 & 218 & 64 & 32 & 11 & 378 \\
\hline My parents' advice & 31 & 96 & 194 & 48 & 19 & 388 \\
\hline My relatives (besides parents) & 2 & 7 & 29 & 77 & 54 & 169 \\
\hline Inspiration from successful people & 3 & 9 & 32 & 55 & 44 & 143 \\
\hline My friends' advice & 1 & 8 & 18 & 40 & 55 & 122 \\
\hline My high school teachers' advice & 1 & 2 & 18 & 42 & 42 & 105 \\
\hline $\begin{array}{l}\text { Advice from my relatives/friends who } \\
\text { are university students }\end{array}$ & 4 & 8 & 25 & 62 & 79 & 178 \\
\hline $\begin{array}{l}\text { Information from internet, including } \\
\text { discussion in social media }\end{array}$ & 0 & 9 & 17 & 24 & 31 & 81 \\
\hline Online promotion (website) & 1 & 0 & 3 & 7 & 23 & 34 \\
\hline $\begin{array}{l}\text { Offline promotion (brochure, exhibition, } \\
\text { etc.) }\end{array}$ & 0 & 2 & 9 & 22 & 45 & 78 \\
\hline Others & 5 & 1 & 2 & 2 & 4 & 14 \\
\hline
\end{tabular}

Table 3. Influential Factors Related to Attributes from Higher Education Institutions

\begin{tabular}{|c|c|c|c|c|c|c|}
\hline Factors & Rank \#1 & Rank\#2 & Rank \#3 & Rank \#4 & Rank \#5 & Total \\
\hline Reputation & 216 & 58 & 28 & 21 & 19 & 342 \\
\hline Values & 35 & 66 & 46 & 42 & 30 & 219 \\
\hline Achievement of the students & 21 & 35 & 77 & 30 & 34 & 197 \\
\hline Success of the alumni & 35 & 71 & 36 & 55 & 24 & 221 \\
\hline Non-academic activities & 14 & 23 & 35 & 32 & 49 & 153 \\
\hline Access to campus & 15 & 32 & 28 & 36 & 32 & 143 \\
\hline Lecturers' quality & 26 & 44 & 42 & 36 & 33 & 181 \\
\hline Affordable cost & 31 & 37 & 42 & 45 & 35 & 190 \\
\hline $\begin{array}{l}\text { Physical facilities (building, parking } \\
\text { space, classrooms, etc.) }\end{array}$ & 9 & 29 & 38 & 55 & 41 & 172 \\
\hline $\begin{array}{l}\text { Supporting facilities (internet, } \\
\text { computer lab, etc.) }\end{array}$ & 12 & 15 & 34 & 31 & 70 & 162 \\
\hline Comfortable environment in campus & 8 & 7 & 11 & 24 & 26 & 76 \\
\hline Safety in campus area & 2 & 6 & 5 & 9 & 23 & 45 \\
\hline Others & 2 & 3 & 1 & 3 & 2 & 11 \\
\hline
\end{tabular}

\section{CONCLUSION AND RECOMMENDATIONS}

Based on the analysis of 426 high school students, student characteristics and parent's advice are the significant factors that will influence the high school students in choosing their place of study. The top three factors that will influence the high school students in choosing higher education institutions are their personal interest, the advice from the parents, and their ability to follow the courses in the particular program. In total, 419 respondents agree that personal interest is the influential factor in deciding an institution, 388 respondents agree that the advice from parents are also important, and 378 respondents agree that their ability to follow the courses are also important in choosing an institution.

For the attributes of the higher education institutions, the high school students consider the reputetion of the institution, the success of the alumni as well as the values held by the institution as the three main factors that will influence them in choosing higher education institution. About $80.28 \%$ considers reputation as the most important factor in choosing a higher education institution, followed by the success of the alumni $(51.88 \%)$ and the values held by the institution (51.41\%).

As being mentioned earlier, this research is done in order to help one of the best private universities in Surabaya to be able to increase its competitiveness in the future. Based on the results of the research, several suggestions for the private university can be made:

1. The potential students should be given clear and detailed information about the programs in the university so that they can know whether the program is matched with their personal interest or not. For example, each representative from each program can give presentation about the programs during the education exhibition or high school 
visit. By doing so, the potential students will have detailed information about the programs.

2. The potential students should be given a chance to experience some classes in the programs that they are interested so that they will have some idea what the program will look like and whether the program matches their interest or not. By doing so, the high school students can know whether the program matches with their interest or whether they are able to follow the courses or not.

3. The university should actively build its reputation and promote its achievement through media. For example, when its students win some competition or create a very unique product, the university should contact the media so that the media can put it in the newspaper or any news media. By doing so, the public, including the parents, will know the quality of the students of the university. This will not only build the reputation, but it will also influence the parents of the potential students, especially when parents' advice is also one of the influential factors to choose a higher education institution.

4. The university should maintain the relationship with the alumni. Based on the research, the success of alumni is also one of the significant influential factors in choosing a higher education institution. By inviting alumni to share their success stories in some events held by the university, the university will not only be able to build its reputation, but it will also be able to inform the potential students that the alumni of the university do well after they have graduated from the university.

5. The university should also ensure that its Christianity values are being inserted in all activities that are done by the university. Nowadays, being excellently academic is not the only thing, but characters and values held by people are also important. Thus, by having students and alumni with strong academic performance as well as strong Christianity values in everything that they do will create a different image of the university in the eyes of the public.

\section{REFERENCES}

Afful-Broni, A. \& Noi-Okwei, C. (2010). Factors Influencing the Choice of Tertiary Education in a Subsaharan African University. Academic Leadership: The Online Journal. 8(2), 1-8.

Ancheh, K. S. B., Krishnan, A. \& Nurtjahja, O. (2007). Evaluative Criteria for Selection of Private Universities and Colleges in Malaysia.
Journal of International Management Studies, 2(1), 1-11.

Baharun, R (2002). A study of market segmentation in tertiary education for local public higher learning institutes. Malaysian Management Review. 37(1).

Bloching, Prof. Dr. B. \& Posdorf, D. (2013). The RB Profiler. Roland Berger Strategy Consultants.

Briggs, S. (2006). An Exploratory Study of the Factors Influencing Undergraduate Student Choice: The Case of Higher Education in Scotland. Studies in Higher Education. 31(6), 705-722.

Burns, M. J. (2006). Factors Influencing The College Choice of African-American Students Admitted to The College of Agriculture, Food, and Natural Resources. University of Missouri-Columbia.

Cabrera, A. F. \& La Nasa, S. M. (2000). Understanding the College-Choice Process. New Directions for Institutional Research. 107, 5-22

Ceja, M. (2001). Applying, Choosing, and Enrolling in Higher Education: Understanding the College Choice Process of First-Generation Chicana Students. University of California, Los Angeles.

Ceja, M. (2006). Understanding the Role of Parents and Siblings as Information Sources in the College Choice Process of Chicana Students. Journal of College Student Development. 47(1), 87-104.

Chapman, D. W. (1981). A Model of Student College Choice. Journal of Higher Education. 52 (5), 490-505.

Chapman, R. G. \& Jackson, R. (1987). College Choices of Academically Able Students: The Influence of No-Need Financial Aid and Other Factors. Research Monograph No. 10. New York, NY: College Board Publications.

Christie, H., Munro, M., \& Fisher, T. (2004). Leaving University early: exploring the differences between continuing and non continuing student. Studies in Higher Education. 29(5), 617-636.

Fizer, D. (2013). Factors Affecting Career Choices of College Students Enrolled in Agriculture. The University of Tennese, Martin.

Goenner, C. \& Snaith, S. (2004). Assessing the Effects of Increased Admission Standards. College and University. 80(1), 29-34.

Hossler, D., Schmidt, J. \& Vesper, N. (1999). Going to College: How Social, Economic and Educational Factors Influence the Decision Students Make. Baltimore, MD, The Johns Hopkins University Press.

Ministry of Education and Culture. (2012). Indonesia Educational Statistics in Brief 2011/2012. 
Irwin, J. V. (2008). The Influence of Self-Efficacy on the College Choice Process: A Comparative Study of Private Four-Year University, Public Four-Year University, and Community College Students. American University.

Islamic University of Indragiri. (n.d.) Perkembangan Jumlah Perguruan Tinggi. Retrieved January 9, 2015, from http://www.unisi.ac.id.

Ismail, N., et al. (2009). Determining Mediating Effect of Information Satisfaction on International Students' College Choice: Empirical Evidence in Malaysia's University. International Journal of Scientific Research in Education (IJSRE). 3(1), 51-63.

Kaze, V. (2010). The Impact of Customer Values on Purchasing Behaviour: A Case of Latvian Insurance Market. Economics and Management, 15.

Kim, D. O. \& Schneider, B. (2005). Social Capital in Action: Alignment of Parental Support in Adolescents' Transition to Postsecondary Education. Social Forbes. 84(2), 1181-1206.

Kopertis Wilayah XII Maluku and North Maluku. 7 February 2013. Peringkat Perguruan Tinggi Indonesia Versi Webometrics Edisi Januari 2013. Retrieved December 12, 2014, from http://www.kopertis12.or.id.

Kopertis Wilayah XII Maluku and North Maluku. 16 August 2013. Peringkat Perguruan Tinggi Indonesia Versi Webometrics Edisi Juli 2013. Retrieved December 12, 2014, from http://www. kopertis12.or.id.

Kopertis Wilayah XII Maluku and North Maluku. 12 February 2014. Peringkat Perguruan Tinggi Indonesia Versi Webometrics Edisi Januari 2014. Retrieved December 12, 2014, from http://www.kopertis12.or.id.

Kopertis Wilayah XII Maluku and North Maluku. 11 August 2014. Peringkat Perguruan Tinggi Indonesia Versi Webometrics Edisi Juli 2014. Retrieved December 12, 2014, from http://www. kopertis12.or.id.

Kusumawati, A., Yanamandram, V. K., \& Perera, N. (2010). Exploring Student Choice Criteria for Selecting an Indonesian Public University: A Preliminary Finding. ANZMAC 2010 Doctoral Colloquium (pp. 1-27). Christchurch, New Zealand: ANZMAC

Mahani, S., \& Molki, A. (2011). Factors influencing female Emirati students' decision to study engineering. Global Journal of Engineering Education. 13(1), 26-31.

Manski, C. F. \& Wise, D. A. (1983). College Choice in America. Cambridge, MA: Harvard University Press.

McInnis, C., James, R., \& Hartley, R. (2000). Trends in first year experience. Evaluation and inves- tigation program, Higher Education Division on 00/6. Canberra: Department of Education, Training and Youth Fair.

Ming, J. S. K. (2010). A Model of Higher Education Institutions Choice in Malaysia - A Conceptual Approach. Curtin University of Technology (Sarawak Campus).

Misran, N., et al. (2012). Malaysia Matriculation Student's Factors in Choosing University and Undergraduate Program. Asian Social Science. $8(16)$.

Moogan, Y. J. \& Baron, S. (2003). An Analysis of Student Characteristics Within the Student Decision Making Process. Journal of Further and Higher Education. 27(3). 271-287.

Munir, S. (2014, May 29). Jokowi Tekankan Pentingnya Perbaikan Kualitas Pendidikan. Sindonews. com. Retrieved January 9, 2015, from http:// www.sindonews.com.

Mustapha, R., \& Long, N. L. (2010). Career decision process among women in technical fields. Paper presented at the 1st International Conference on Technical and Vocational Education and Training, 10-11 November, in Bandung.

Pangkalan Data Pendidikan Tinggi Direktorat Jenderal Pendidikan Tinggi (PDDIKTI). (n.d.). Grafik Jumlah Perguruan Tinggi. Retrieved January 9, 2015, from http://forlap.dikti.go.id.

Pentingnya Pendidikan di Indonesia. (2014, August 25). Kompasiana.

Schoenherr, H. J. (2009). Beyond academic reputetion: Factors that influence the college of first choice for high achieving students. University of South Florida.

Sevier, R.A. (1997). Major trends affecting higher education. Presentation conducted at the Symposium for the Marketing of Higher Education, Boston, MA.

Seymour, E., \& Hewitt, N. M. (1997). Talking about leaving: Why undergraduates leave the sciences. Boulder. CO: Westview Press.

Surabaya.go.id. (n.d.). Pendidikan. Retrieved July 14, 2015, from http://www.surabaya.go.id

UNESCO Institute for Statistics. (n.d.) School enrollment, tertiary (\% gross). Retrieved March 11, 2015, from http://data.uis.unesco.org.

Yiv, C. \& Secombe, M. J. (1999). Cambodian students and motivation to participate in higher education. Education and Society, 17(2), 85-98.

Wiese, M., van Heerden, N., Jordaan, Y., \& North, E. (2009). A Marketing Perspective on Choice Factors Considered by South African First Year Students in Selecting a Higher Education Institution. Southern African Business Review, 13(1), $39-60$. 